\title{
Ishak Score 2
}

National Cancer Institute

\section{Source}

National Cancer Institute. Ishak Score 2. NCI Thesaurus. Code C95152.

Minimal fibrosis in most portal areas. 